Gitation: Aguilar-Ovando, B., Calderón-Domínguez, G., GarcíaGaribay, M., Jiménez-Guzmán, J., Jardón-Valadez, E., León-Espinosa, E. B., Cruz-Monterrosa, R. G., CortésSánchez, A. de J., Ruíz-Hernández, R., Díaz-Ramírez, M. (2021). $\beta$-lactoglobulin peptides obtained by chymotrypsin hydrolysis Agro Productividad. https://doi.org/10.32854/ agrop.v14i9.2144

Editor in Chief: Dr. Jorge Cadena Iñiguez

Received: February 23, 2021. Accepted: August 18, 2021.

Published on-line: October 12, 202

This work is licensed under a Creative Commons Attribution-NonCommercial 4.0 International license.

\section{$\beta$-lactoglobulin peptides obtained by chymotrypsin hydrolysis}

\author{
Aguilar-Ovando, Brayan ${ }^{1}$; Calderón-Domínguez, Georgina ${ }^{2}$; García-Garibay, Mariano ${ }^{1}$; \\ Jiménez-Guzmán, Judith ${ }^{1}$; Jardón-Valadez, Eduardo ${ }^{3}$; León-Espinosa, Erika B. ${ }^{1}$; \\ Gruz-Monterrosa, Rosy G. ${ }^{1}$; Cortés-Sánchez, Alejandro de Jesús ${ }^{4}$; Ruíz-Hernández, Rafael ${ }^{5}$; \\ Díaz-Ramírez, Mayra ${ }^{1 *}$
}

1 Departamento de Ciencias de la Alimentación. División de Ciencias Biológicas y de la Salud. Universidad Autónoma Metropolitana Unidad Lerma. Av. De las Garzas 10, El panteón, 52005 Lerma de Villada, Estado de México.

2 Departamento de Ingeniería Bioquímica. Escuela Nacional de Ciencias Biológicas. Instituto Politécnico Nacional. Unidad Profesional Adolfo López Mateos, Zacatenco, Av. Wilfrido Massieu 399, Col. Nueva Industrial Vallejo, Alcaldía Gustavo A. Madero C.P. 07738, Ciudad de México, México.

3 Departamento de Ciencias de la Tierra. División de Ciencias Básicas e Ingeniería. Universidad Autónoma Metropolitana Unidad Lerma. Av. De las Garzas 10, El panteón, 52005 Lerma de Villada, Estado de México.

4 Consejo Nacional de Ciencia y Tecnología (CONACYT). Unidad Nayarit del Centro de Investigaciones Biológicas del Noroeste (UNGIBNOR+). Calle Dos No. 23. Gd. del Conocimiento. Av. Emilio M. González C.P. 63173. Tepic, Nayarit. México.

5 Catédra COMECyT adscrito al Departamento de Ciencias de la Alimentación. División de Ciencias Biológicas y de la Salud. Universidad Autónoma Metropolitana Unidad Lerma. Av. De las Garzas 10, El panteón, 52005 Lerma de Villada, Estado de México.

* Correspondence: m.diaz@correo.ler.uam.mx

\begin{abstract}
Objective: Whey proteins, as $\beta$-lactoglobulin, have biological activity. Controlled hydrolysis of this protein could generate peptides with some biological function. The aim of this work was to analyze the peptides resulting from the in vitro hydrolysis with chymotrypsin in order to evaluate the presence of bioactive peptides. Design/methodology/approach: Chymotrypsin was used in the hydrolysis of $\beta$-lactoglobulin, and its peptides were evaluated by ultrafiltration, electrophoresis, and mass spectrometry.

Findings/conclusion: Results showed that $2 \mathrm{~h}$ of chymotrypsin hydrolysis $(\mathrm{T} 1)$ released peptides with molecular weight values of 8 and $9 \mathrm{KDa}$, while $4 \mathrm{~h}$ of hydrolysis (T2) produced peptides with molecular mass weight values of 7 and $5 \mathrm{KDa}$. The mass spectrometry (MALDI-TOF) showed six peaks and five of them were comparable with those obtained by in silico hydrolysis results (done previously by Fonseca Ayala, 2018). The identified peptides (DTDYK, DAQSAPL and LKPTPEGDL) in the fraction $<1 \mathrm{kDa}$ showed inhibitory activity of angiotensin converting enzyme and inhibitory activity of enzyme dipeptidyl peptidase IV according BIOPEP database. These results showed that $\beta$-lactoglobulin peptides obtained by chymotrypsin hydrolysis could have biological activity that can be used in different types of industries as pharmaceutical and food.

Limitations on study/implications: The in vitro evaluation of the biological activity of the characterized peptides is necessary.
\end{abstract}

Key words: $\beta$-lactoglobulin, hydrolysis, biopeptides, chymotrypsin

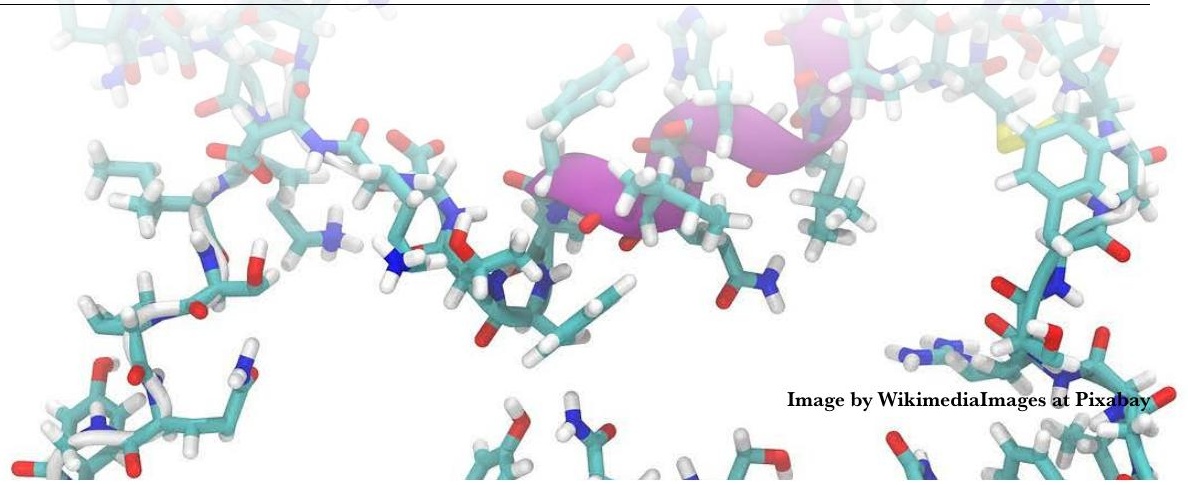




\section{INTRODUCTION}

Bioactive peptides are protein fragments that have a positive effect on body functions and health (Remanan and Wu, 2014; Sharma et al., 2011), this fact has increased their scientific and commercial interest (Korhonen, 2009). These peptides are inactive within the protein, but they can be released during enzymatic hydrolysis under specific conditions in the gastrointestinal tract, therefore enzymes as pepsin, trypsin and chymotrypsin have been used. Antimicrobial, antithrombotic, antihypertensive, opioid, immunomodulatory, and antioxidant activities had been described and such activities depends on their amino acids sequence and composition (Escudero et al., 2012).

$\beta$-Lactoglobulin is the main protein in whey, it has antioxidant activity and maintains retinol absorption levels in dermal cells, it also has emulsifying capacity derived from its amphiphilic structure (Pihlanto-Leppälä, 2000). Besides, bioactive peptides of this protein with different biological activities have been described such as ACE inhibitory activity (Hernández-Ledesma et al., 2011; Pihlanto-Leppälä, 2000), dipeptidyl peptidase IV inhibitory activity (Girolamo et al., 2008) antimicrobial capacity (Mulero et al., 2011), and some peptides had been used with others showed a positive effect on metabolic syndrome (Ricci-Cabello et al., 2012).

Recently, Fonseca Ayala (2018) determined the bioactivity of peptides obtained by in silico hydrolysis of $\beta$-Lactoglobulin with different enzymes (chymotrypsin, trypsin and pepsin) where 29 peptides were obtained by chymotrypsin hydrolysis and three of them have biological activity according BIOPEP database. Their results show that chymotrypsin hydrolysis in vitro could produce bioactive peptides. Therefore, the objectives of this work were to do the in vitro hydrolysis of $\beta$-lactoglobulin with chymotrypsin and to compare the produced peptides with those obtained by in silico hydrolysis.

\section{MATERIALS AND METHODS}

\section{Materials}

Bovine lyophilized $\beta$-lactoglobulin (purity $>/=90 \%$ ) (L3908 Sigma-Aldrich), and $\beta$-chymotrypsin from bovine pancreas type II (C4129 Sigma-Aldrich). All materials were reagent grade.

\section{Methods}

Chymotrypsin hydrolysis. The hydrolysis was carried out according to Gillespie $e t$ al. (2015) with some modifications. $0.2 \mathrm{~g}$ of $\beta$-lactoglobulin was added to $25 \mathrm{ml}$ of phosphates buffer $\mathrm{pH} 7.4$ after, chymotrypsin was added in a 1:25 proportion enzyme/substrate, the reaction was done at $37^{\circ} \mathrm{C}$ in agitation. Three hydrolyzed solutions were obtained, T0: without reaction time, $\mathrm{T} 1: 2 \mathrm{~h}$ of reaction, $\mathrm{T} 2: 4 \mathrm{~h}$ of reaction. The inactivation of the enzyme was carried out at $90{ }^{\circ} \mathrm{C}$ during $2 \mathrm{~min}$. The hydrolyzed solutions were stored at freezing $\left(-20^{\circ} \mathrm{C}\right)$ until their analysis.

Degree of hydrolysis. A pH method was carried out where the samples were titrated with $\mathrm{NaOH}(0.1 \mathrm{~N})$ in order to maintain the optimal $\mathrm{pH}$ of the enzyme. The degree of hydrolysis $(\% \mathrm{DH})$ were calculated with Equation 1 (Adler-Nissen, 1979; Fernández and Kelly, 2016). 


$$
D H(\%)=\left[\frac{\beta \times N b}{\alpha \times M p \times H t o t}\right] \times 100
$$

where: $\beta$ : $(\mathrm{mL})$ volume of the $\mathrm{NaOH}$ solution added during the hydrolysis. $N b$ : $(\mathrm{eq} / \mathrm{L})$ is the normality of the $\mathrm{NaOH}$ solution. $M p$ : $\mathrm{g}$ of the protein in the reaction. Htot: (mequiv/g) total number of peptide bonds in the substrate. $\alpha$ : degree of dissociation of $\beta$-amino groups released during the hydrolysis. Both, Htot (8.8) and $\alpha$ (1) values were obtained from the literature (Nielsen et al., 2001).

Ultrafiltration of the hydrolyzed solutions. The hydrolyzed solutions were ultrafiltrated using a shaking chamber (Amicon 8010 Millipore) with a capacity of $10 \mathrm{~mL}$ and a membrane filtration of $4.1 \mathrm{~cm}^{2}$ of area (regenerated cellulose, Ultracel ${ }^{\circledR}$ ). Membranes had a molecular scale of 5, 3 and $1 \mathrm{KDa}$ and were hydrated in distilled water for $2 \mathrm{~h}$ before the ultrafiltration. The separation was carried out at a pressure of $25 \mathrm{psi}$ with $\mathrm{N}_{2}$ and at a temperature of $25^{\circ} \mathrm{C}$, and in three stages: 1) The hydrolyzed solution (T1, T2) (10 mL) was put into the chamber with a $5 \mathrm{KDa}$ membrane and the permeated solution was obtained, 2) this permeated solution ( $5 \mathrm{KDa}$ ) was put into the chamber with a $3 \mathrm{KDa}$ membrane and the permeated solution was recovered, 3) the second permeated solution (3 KDa) was put into the chamber with a $1 \mathrm{KDa}$ membrane. All permeated solutions were store at freezing $\left(-20^{\circ} \mathrm{C}\right)$ until their analysis.

SDS-PAGE/ Tricine polyacrylamide Gel Electrophoresis. a) Pre-electrophoresis sample preparation: $10 \mu \mathrm{L}$ of sample [BSA; $\beta$-LG; 1 KDa permeated solution and unfiltered hydrolyzed solutions (T0, T1, T2) were added to $25 \mu \mathrm{L}$ of buffer (TruPAGE $4 \mathrm{x}$ PCG3009, Sigma Aldrich) with $65 \mu \mathrm{L}$ of distilled water. The mixture was stirred for $5 \mathrm{~s}$ until homogenized and heated at $70^{\circ} \mathrm{C}$ during $10 \mathrm{~min}$ and cooled to $-5^{\circ} \mathrm{C}$ during $10 \mathrm{~min}$ before the analysis. The markers (Sigma S8445-10VL) (200000-6500 KDa) were prepared according to the manufacturer. b) SDS-PAGE/Tricine polyacrylamide gel Electrophoresis: The samples were analyzed by electrophoresis using a Mighty Small II SE 250 camera (Hoefer Scientific Instruments). A precast 20\% to 4\% gradient gel with 12 wells was used. The electrophoretic run was carried out at a voltage of 100 volts during $2 \mathrm{~h}$. $10 \mu \mathrm{L}$ of the samples and the marker were injected into each well of the gel.

Molecular weights values of the peptides of permeated solution $(<1 \mathrm{KDa})$ by Mass Espectrometry (MALDI-TOF / TOF). The Autoflex Speed equipment (Bruker Daltonics) was used. The permeated solution $<1 \mathrm{KDa}$ of both chymotrypsin hydrolyzed solutions ( $\mathrm{T} 1$ and $\mathrm{T} 2$ ) were dissolved in a $0.1 \%$ trifluoroacetic acid solution with three parts of acetonitrile. This mixture was prepared with a 1:1 matrix: sample ratio. The matrix was alpha-cyano-4-hydroxycinnamic acid (Sigma Aldrich). The analysis of the permeated solutions was carried out in the range between 700 and 3500 Da. The identified peaks (peptides) in the spectrogram were compared to the molecular weights values obtained by in-silico hydrolysis carried out by Fonseca Ayala (2018). After that, the possible bioactivity of these peptides was identified in the BIOPEP database. 


\section{RESULTS AND DISCUSSION}

The chymotrypsin hydrolysis and evaluation of the degree of hydrolysis $(\mathrm{DH})$ by $\mathrm{pH}$ stat method were carried out simultaneously, results (Table 1) show that the DH was higher at $4 \mathrm{~h} \mathrm{(T2)} \mathrm{(25.5 \% )} \mathrm{than} 2 \mathrm{~h}$ (T1) (22\%), and these values are according to Tulipano et al. (2015) who obtained similar DH values. pH-stat method measures the protons released from the active site of chymotrypsin by their catalytic activity and indirectly determines the cleavage of the peptide bond by the number of amino groups released.

After hydrolysis, the fractions were analyzed by SDS-PAGE gel electrophoresis, the results (Figure 1 and Table 2) show that hydrolyzed fractions had different molecular

Table 1. Degree of Hydrolysis after 2 (T1) and 4(T2) h of hydrolysis using chymotrypsin.

\begin{tabular}{|c|c|c|}
\hline \multicolumn{3}{|c}{ Degree Hydrolysis (\%DH) } \\
\hline T0 & T1 & T2 \\
\hline 0 & $22 \%$ & $25.52 \%$ \\
\hline
\end{tabular}

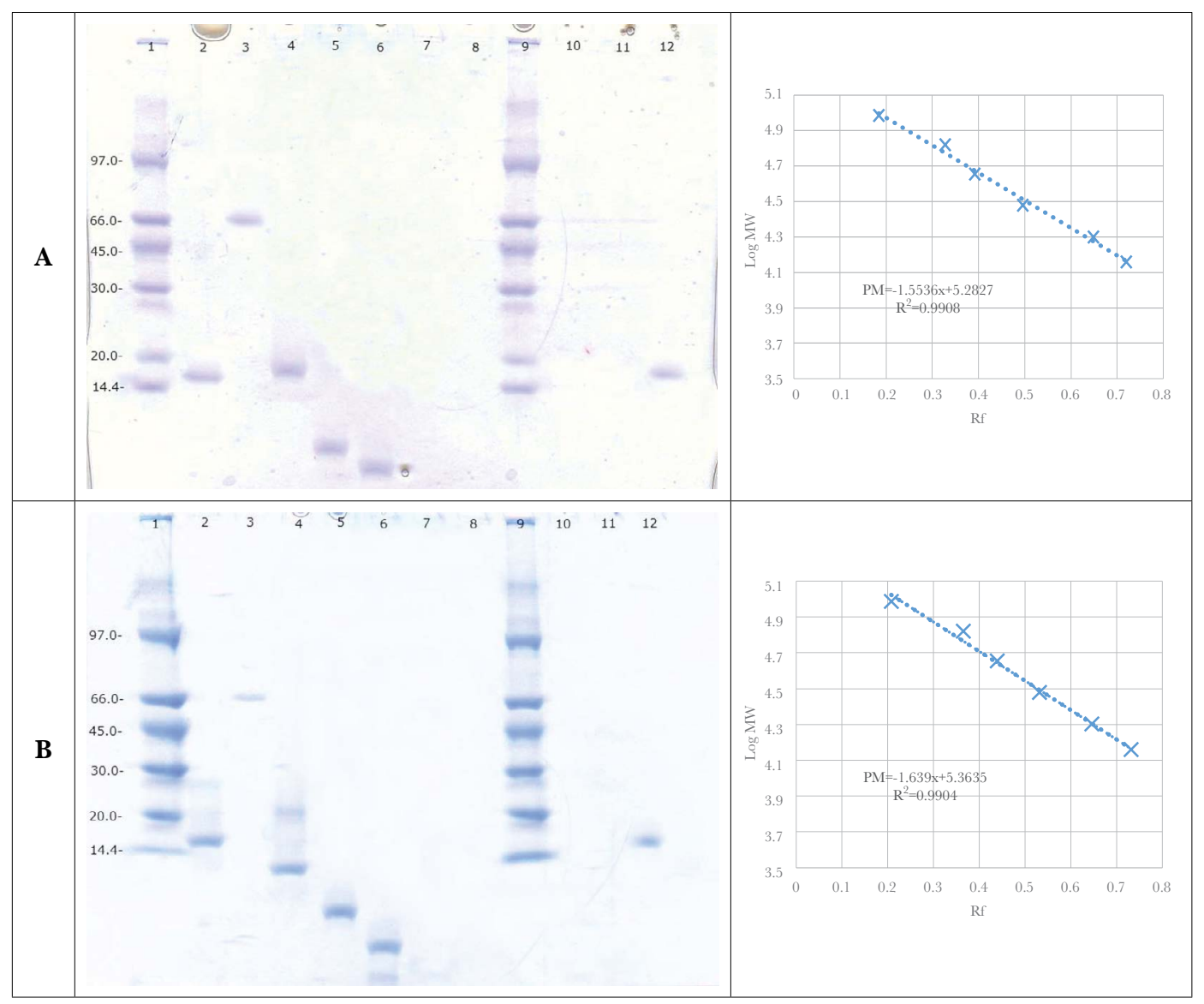

Figure 1. Images of electrophoresis gels of different fractions after chymotrypsin hydrolysis (A) and linear regression of the Rf vs Log molecular weight $(\operatorname{LogMW})(B) .1)$ Low spectrum standard (97.0-14.4 KDa); 2) $\beta$-Lg (1mg/mL); 3) BSA (1mg/ml); 4) T0; 5) T1; 6) T2; 7) Permeated solution <1 KDa of T1 8); Permeated solution <1 KDa of T2; 9) Low spectrum standard (97.0-14.4 KDa); 10) Permeated solution <1 KDa of T1; 11) Permeated solution <1 KDa of T2; 12) $\beta$-Lg $(1 \mathrm{mg} / \mathrm{L})$. 
Table 2. Molecular weight values identified by the linear regression analysis of $\mathrm{Rf}$ and $\log \mathrm{WM}$ of electrophoresis gel of chymotrypsin hydrolyzed fractions.

\begin{tabular}{l|c|c|c|c|c|c}
\hline \multirow{2}{*}{ Samples } & \multicolumn{3}{|c|}{ Gel 1 } & \multicolumn{2}{c}{ Gel 2 } \\
\cline { 2 - 7 } & Rf & Log PM & PM(Da) & Rf & Log PM & PM(Da) \\
\hline$\beta$-Lg & 0.696 & 4.2014 & 15899.90 & 0.646 & 4.2713 & 18676.69 \\
\hline BSA & 0.328 & 4.7731 & 59308.81 & 0.3 & 4.8563 & 71829.03 \\
\hline T0 & 0.688 & 4.2138 & 16361.50 & 0.712 & 4.1608 & 14481.05 \\
\hline T1 & 0.864 & 3.9404 & 8717.45 & 0.815 & 3.9853 & 9667.18 \\
\hline T2 & 0.92 & 3.8534 & 7134.90 & 0.9 & 3.8423 & 6955.046 \\
\hline T2.b & & & & 0.96 & 3.25 & 4950.365 \\
\hline
\end{tabular}

weight values, T0 had values around 16 or $14 \mathrm{KDa}$ similar to the molecular weight of $\beta$-Lg, which molecular weight was $15 \mathrm{KDa}(\mathrm{Gel} \mathrm{1)}$ and $18 \mathrm{KDa}(\mathrm{Gel} 2)$. T1 had fractions of 8 $\mathrm{KDa}(\mathrm{Gel} \mathrm{1)}$ and $9 \mathrm{KDa}(\mathrm{Gel} 2)$, while T2 had fractions of $7 \mathrm{KDa}(\mathrm{Gel} 1$ and 2) and $5 \mathrm{KDa}$ (Gel 2). Also, a fraction <1 KDa was analyzed, but no bands were presented because of the gel sensibility. These results showed that as the chymotrypsin hydrolysis time increased hydrolyzed fractions had lower molecular weight values.

The portions < $1 \mathrm{KDa}$ of both hydrolyzed fractions (T1 and T2) were analyzed in the mass spectrometer in order to know the molecular weight of their peptides, however only the spectrogram of T1 had six identified peaks (Table 3). These molecular weight values were compared with the peptides obtained by in silico hydrolysis (Fonseca Ayala, 2018) but only five peptides were comparable with them. Also, three peptides (2, 5 and 6$)$ could have bioactivity as ACE inhibitory activity and Dipeptidyl peptidase IV inhibitory activity and peptides 2, 4 and 6 could have antibacterial activity, because similar sequences were described in the BIOPEP database. However, the in vitro analysis of the biological activity of these peptides is necessary to corroborate these results.

Table 3. Molecular weight values of T1 identified by mass spectroscopy and its sequence identified by in silico hydrolysis.

\begin{tabular}{|c|c|c|c|c|}
\hline No. & $\begin{array}{l}\text { Molecular weight } \\
\text { values of } \mathrm{T} 1\end{array}$ & Sequence & $\begin{array}{l}\text { Sequence identified in } \\
\text { BIOPEP database }\end{array}$ & $\begin{array}{l}\text { Bioactivity reported in the } \\
\text { BIOPEP database }\end{array}$ \\
\hline 1 & $620.3 \mathrm{Da}$ & & & \\
\hline \multirow{3}{*}{2} & \multirow{3}{*}{$643.22 \mathrm{Da}$} & \multirow{3}{*}{ DTDYK } & VLDTDYK & ACE inhibitor \\
\hline & & & VLVLDTDYK & Antibacterial \\
\hline & & & VLVLDTDYK & Dipeptidyl peptidase IV inhibitor \\
\hline 3 & $656.85 \mathrm{Da}$ & EEQCH & & \\
\hline 4 & $686.74 \mathrm{Da}$ & AASDISL & AASDISLLDAQSAPLR & Antibacterial \\
\hline \multirow{3}{*}{5} & \multirow{3}{*}{$716.80 \mathrm{Da}$} & \multirow{3}{*}{ DAQSAPL } & LDAQSAPLR & ACE inhibitor \\
\hline & & & AASDISLLDAQSAPLR & Antibacterial \\
\hline & & & DAQSAPLRVY & ACE inhibitor \\
\hline \multirow{2}{*}{6} & \multirow{2}{*}{$742.70 \mathrm{Da}$} & \multirow{2}{*}{ LKPTPEGDL } & LKPTPEGDL & Dipeptidyl peptidase IV inhibitor \\
\hline & & & LKPTPEGDLEIL & Dipeptidyl peptidase IV inhibitor \\
\hline
\end{tabular}




\section{GONGLUSIONS}

Chymotrypsin hydrolysis produced fractions of $8 \mathrm{KDa}$ and $9 \mathrm{KDa}$ at $2 \mathrm{~h}$, and $7 \mathrm{KDa}$ and $5 \mathrm{KDa}$ at $4 \mathrm{~h}$ of hydrolysis. Mass spectrometry identified six peptides in the hydrolyzed solution (T1, 2h), where five of them were comparable with peptides previously obtained by in silico hydrolysis. The sequences of the peptides identified (DTDYK, DAQSAPL and LKPTPEGDL) showed bioactivity according BIOPEP database.

\section{ACKNOWLEDGMENTS}

The authors would like to thank CONACyT for financial support by project 255741 .

\section{REFERENGES}

Adler-Nissen, J. (1979). Determination of the degree of hydrolysis of food protein hydrolysates by trinitrobenzenesulfonic acid. Journal of Agricultural and Food Chemistry, 27(6), 1256-1262. https://doi. org/10.1021/jf60226a042

Girolamo Di, G., Tamez, A., \& Tamez, H. (2008). Inhibidores de la dipeptidil peptidasa-4: Farmacodinamia, farmacocinética y seguridad. Med Int Mex., 24(2)

Escudero, E., Mora, L., \& Toldrá, F. (2014). Stability of ACE inhibitory ham peptides against heat treatment and in vitro digestion. Food Chemistry, 161, 305-311. https://doi.org/10.1016/j.foodchem.2014.03.117

Escudero, E., Toldrá, F., Sentandreu, M. A., Nishimura, H., \& Arihara, K. (2012). Antihypertensive activity of peptides identified in the in vitro gastrointestinal digest of pork meat. Meat Science, 91(3), 382-384. https://doi.org/10.1016/j.meatsci.2012.02.007

Fernández, A., \& Kelly, P. (2016). pH-stat vs. free-fall pH techniques in the enzymatic hydrolysis of whey proteins. Food Chemistry, 199, 409-415. https://doi.org/10.1016/j.foodchem.2015.12.043

Fonseca Ayala Minerva. 2018. Estudio in silico de la obtención de péptidos con actividad biológica a partir de hidrólisis enzimática de $\beta$-lactoglobulina. Tesis de Maestría. Instituto Politécnico Nacional. México.

Gillespie, A. L., Calderwood, D., Hobson, L., \& Green, B. D. (2015). Whey proteins have beneficial effects on intestinal enteroendocrine cells stimulating cell growth and increasing the production and secretion of incretin hormones. Food Chemistry, 189, 120-128. https://doi.org/10.1016/j.foodchem.2015.02.022

Hernández-Ledesma, B., del Mar Contreras, M., \& Recio, I. (2011). Antihypertensive peptides: Production, bioavailability and incorporation into foods. Advances in Colloid and Interface Science, 165(1), 23-35. https://doi.org/10.1016/j.cis.2010.11.001

Korhonen, H. (2009). Milk-derived bioactive peptides: From science to applications. Journal of Functional Foods, 1(2), 177-187. https://doi.org/10.1016/j.jff.2009.01.007

Mulero Cánovas, J., Zafrilla Rentero, P., Martínez-Cachá Martínez, A., Leal Hernández, M., \& Abellán Alemán, J. (2011). Péptidos bioactivos. Clínica E Investigación En Arteriosclerosis, 23(5), 219-227. https:// doi.org/10.1016/j.arteri.2011.04.004.

Nielsen, P., Petersen, D., \& Dambmann, C. (2001). Improved method for determining food protein degree of hydrolysis. Journal of Food Science, 66(5), 642-646. https://doi.org/10.1111/j.1365-2621.2001.tb04614.x

Pihlanto-Leppälä, A. (2000). Bioactive peptides derived from bovine whey proteins: Opioid and aceinhibitory peptides. Trends in Food Science \& Technology, 11(9), 347-356. https://doi.org/10.1016/S09242244(01)00003-6

Remanan, M., \& Wu, J. (2014). Antioxidant activity in cooked and simulated digested eggs. Food E Function, $5(7), 1464-1474$.

Ricci-Cabello, I., Olalla Herrera, M., \& Artacho, R. (2012). Possible role of milk-derived bioactive peptides in the treatment and prevention of metabolic syndrome. Nutrition Reviews, 70(4), 241-255. https://doi. org/10.1111/j.1753-4887.2011.00448.x

Sharma, S., Singh, R., \& Rana, S. (2011). Bioactive peptides: A review. Int J Bioautomation, 15(4), 223-250.

Tulipano, G., Faggi, L., Nardone, A., Cocchi, D., \& Caroli, A. M. (2015). Characterisation of the potential of $\beta$-lactoglobulin and $\alpha$-lactalbumin as sources of bioactive peptides affecting incretin function: In silico and in vitro comparative studies. International Dairy Journal, 48, 66-72. https://doi.org/10.1016/j. idairyj.2015.01.008 